\section{ASMS News}

\section{WORKSHOP ON ELECTROSPRAY IONIZATION MASS SPECTROMETRY}

The Workshop on Electrospray Ionization Mass Spectrometry will be repeated April 23 and 24, 1993, in Baltimore, Maryland. The same program was overscribed when it was presented in November. The April workshop, organized by James A. McCloskey and Robert C. Murphy, will feature the same speakers including Steven A. Carr, Brian Chait, Thomas Covey, Pamela Crain, Daniel Garteiz, Barbara Larsen, and Marvin Vestal. A keynote lecture will be presented by John Fenn, 1992 Recipient of the ASMS Award for a Distinguished Contribution in Mass Spectrometry for his development of electrospray.

Two enhancements to the previous program will be a two-hour "Introduction to Mass Spectrometry" and a Corporate Poster session. The Introductory program will be conducted by Bob Murphy and Jim McCloskey on Friday morning, April 23, and is intended for those who will utilize or supervise electrospray techniques, but who have little or no background in mass spectrometry. The regular program will commence at $1 \mathrm{pm}$ on Friday afternoon and continue through $5 \mathrm{pm}$ on Saturday. The Corporate Poster Session on Friday evening will provide a look at the presentations on instrumentation.

\section{ST ASMS CONFERENCE ON MASS SPECTROMETRY AND ALLIED TOPICS}

The 41st ASMS Conference on Mass Spectrometry and Allied Topics will be May 30-June 4, 1993, at the Marriott Hotel, San Francisco, California. The program will feature four parallel symposia each morning, afternoon poster sessions, and evening workshops. A one and a half hour lunch break will provide the opportunity for informal lunch gatherings of Interest Groups. Chris Enke, Vice President for Programs, is seeking to enhance the activities of Interest Groups to make participation in ASMS activities and the conference accessible to more people.

\section{ASMS SHORT COURSES}

ASMS Short Courses, May 29-30, 1993, will be conducted immediately preceding the annual conference in San Francisco. All of the six short courses listed below are full two-day programs.

- Introduction to the Interpretation of Mass Spectra, presented by the Baltimore-Washington Mass Spectrometry Discussion Group

- Advanced Interpretation of Mass Spectra, presented by Frank Turecek and Thomas A. Baillie

- GC/MS for Environmental Analysis, organized by Paul Goodley and Norman Low

- Fundamental Aspects of Gas Phase Ions, presented by Robert Squires, Veronica Bierbaum, Scott McLuckey, and Chrys Wesdemiotis

- LC/MS: The Art and The Practice, presented by John Coutant, Robert Voyksner, and Alfred Yergey

- Practical MS/MS Analysis, presented by Jodie Johnson

\section{TH ASILOMAR CONFERENCE ON MASS SPECTROMETRY}

The 10th Asilomar Conference on Mass Spectrometry (ACMS), featuring the topic "Time-of-Flight Mass Spectrometry," will be held October 3-7, 1993. The Program Chairman is Kenneth G. Standing of the University of Manitoba. The conference will focus on the potential and limitations of TOF, aiming to uncover hitherto untapped potentials or new means of enhancing its performance.

In a break from tradition, the conference will not be at Asilomar this year, but at Aspen Lodge, a ranch-style conference center in scenic Estes Park, Colorado. The location offers an ideal environment for informal meetings and a variety of recreational and mountaineering activities.

For further information, contact Laszlo Tokes, Syntex Discovery Research, 3401 Hillview Avenue, Palo Alto, CA 94304. Telephone: (415) 855-5713. 


\section{ASMS CALENDAR}

\section{3}

April 23-24

April 23

May 29-30

May 30-June 4
Workshop on Electrospray Ionization, Baltimore, MD

Deadline for advance conference and short course registration

ASMS Short Courses, Marriott Hotel, San Francisco, CA

41st ASMS Cunference on Mass Spectrometry and Allied Topics,
Marriott Hotel, San Francisco, CA

October 3-7 10th Asilomar Conference on Mass Spectrometry, "Time-ofFlight Mass Spectrometry," Aspen Lodge, Estes Park, CO

The ASMS News is prepared by Judith A. Sjoberg, Executive Director. For additional information, contact ASMS, 815 Don Gaspar, Santa Fe, NM 87501. Telephone: (505) 989-4517.

\section{RELATED EVENTS CALENDER}

10th Montrewx Symposium on LC/MS

July 1993

Short Course

Short Course on LCMS, SFC,MS, CE/MS, and MS/MS, July 19-20, 1993, preceding the 10th Montreux Symposium on LC/MS at Cornell University, Ithaca, NY. Contact: LC/MS Symposium, Cornell Conference Services, Box 3, Robert Purcell Union, Ithaca, NY 14853, phone (607) 255-6290, fax (607) 255-4722.

Symposium 10th Montreux Symposium on LC/ MS, SFC/MS, CE/MS, and MS/MS, to be held at Cornell University, July 21-23, 1993. Contact: LC/MS Symposium, Cornell Conference Services, Box 3, Robert Purcell Union, Ithaca, NY 14853, phone (607) 255-6290, fax (607) 255-4722.

Call for Papers 10th Montreux Symposium on LCf MS, SFC/MS, CE/MS, and MS/MS, to be held at Cornell University, July
21-23, 1993. Deadline for abstract submission, June 1, 1993. Contact: LC/MS Symposium, Cornell Conference Services, Box 3, Robert Purcell Union, Ithaca, NY 14853, Phone (607) 255-6290, fax (607) 255-4722, or Jack Henion, Chairman, Cornell University, 925 Warren Dr., Ithaca, NY 14850, phone (607) 255-6556, fax (607) 255-3235.

A few student grants for waiver of the Symposium registration are available on a competitive basis. Contact Dr. Henion at (607) 255-6556 for details.

Graduate and postdoctoral student registration: Special registration fees are available to matriculated graduate and postdoctoral students. Short Course and Symposium registration costs $\$ 175.00$ per event. Candidates must present documentation of matriculation or postdoctoral position from their research advisor. 